\title{
Short-term Effects of Mowing and Burning on Soil Nutrients in Big Meadows, Shenandoah National Park
}

\author{
NORMAN L. CHRISTENSEN
}

Highlight: Soil concentrations of phosphate, nitrate, ammonium, and exchangeable calcium, magnesium, and potassium were measured before and following burning and mowing in two vegetational types in Big Meadows Shenandoah National Park, Virginia. Burning with or without mowing resulted in significant increase in concentrations of all nutrients except phosphorus. Mowing per se had no effect on nutrient concentrations. The potential use of fire to control hardwood invasion in these meadow areas is discussed.

Among the most striking features of Shenandoah National Park are the large meadow areas along the crest of the Blue Ridge. The largest of these clearings is Big Meadows, occupying over 40 ha (Fig. 1). Besides supporting a high floral and faunal diversity, these clearings provide majestic panoramas of the Shenandoah Valley to the west and Virginia Piedmont to the east. The ontogeny of these clearings has been in dispute for many years. They are almost certainly of human origin and seem not to be related to higher elevation clearings in the more southern reaches of the Appalachians (Mark, 1958; Gersmehl, 1971).

Since the establishment of Shenandoah National Park in 1935, the flora and fauna of these meadow areas have been changing. Of particular concern is the invasion at the meadow margins of several

The author is with the Botany Department, Duke University, Durham, North Carolina 27706.

The author wishes to thank the U.S. National Park Service for financial assistance and D. Cocking and S. Lilly for assistance in the field.

Manuscript received March 10, 1976.

shrubby and arborescent species. As a result many areas formerly dominated by a variety of grasses and sedges are now dominated by black locust (Robinia pseudo-acacia), hawthorn (Crataegus sp.), bracken fern (Pteridium aquilinum), and a variety of other species associated with the adjacent hardwood forests. Associated with the vegetational change, faunal diversity has declined. The thorny, shrubby nature of the invading vegetation makes it virtually impenetrable and tends to obscure the vistas which attract so many visitors (Wilhelm, 1973).

For several years the Park Service has been mowing these meadow areas in an effort to discourage this invasion. This is done in November so as to minimize impact on wildflower displays. Such mowing is expensive and has done little to slow this vegetational change (Wilhelm, 1973). Several authors (Gersmehl, 1971; Wilhelm, 1973) have emphasized the importance of fire in the maintenance of these grassy areas prior to management. With these facts in mind, the U.S. National Park Service initiated a pilot study on the potential use and impact of fire to control shrub invasion.

One of the obvious effects of fire is the immediate release of nutrients previously held in the standing crop. In many grassland areas this release may improve soil fertility, thereby increasing productivity (Vogl, 1975). It may also render many nutrients more susceptible to leaching and thus result in nutrient loss from the ecosystem (Daubenmire, 1968). Nitrogen may be volatilized during fire (DeBell and Ralston, 1970); however, this loss is usually offset by increased rates of nitrogen fixation following burning (Wells, 1971). The actual effects of fire on soil nutrients at any given site may be quite variable

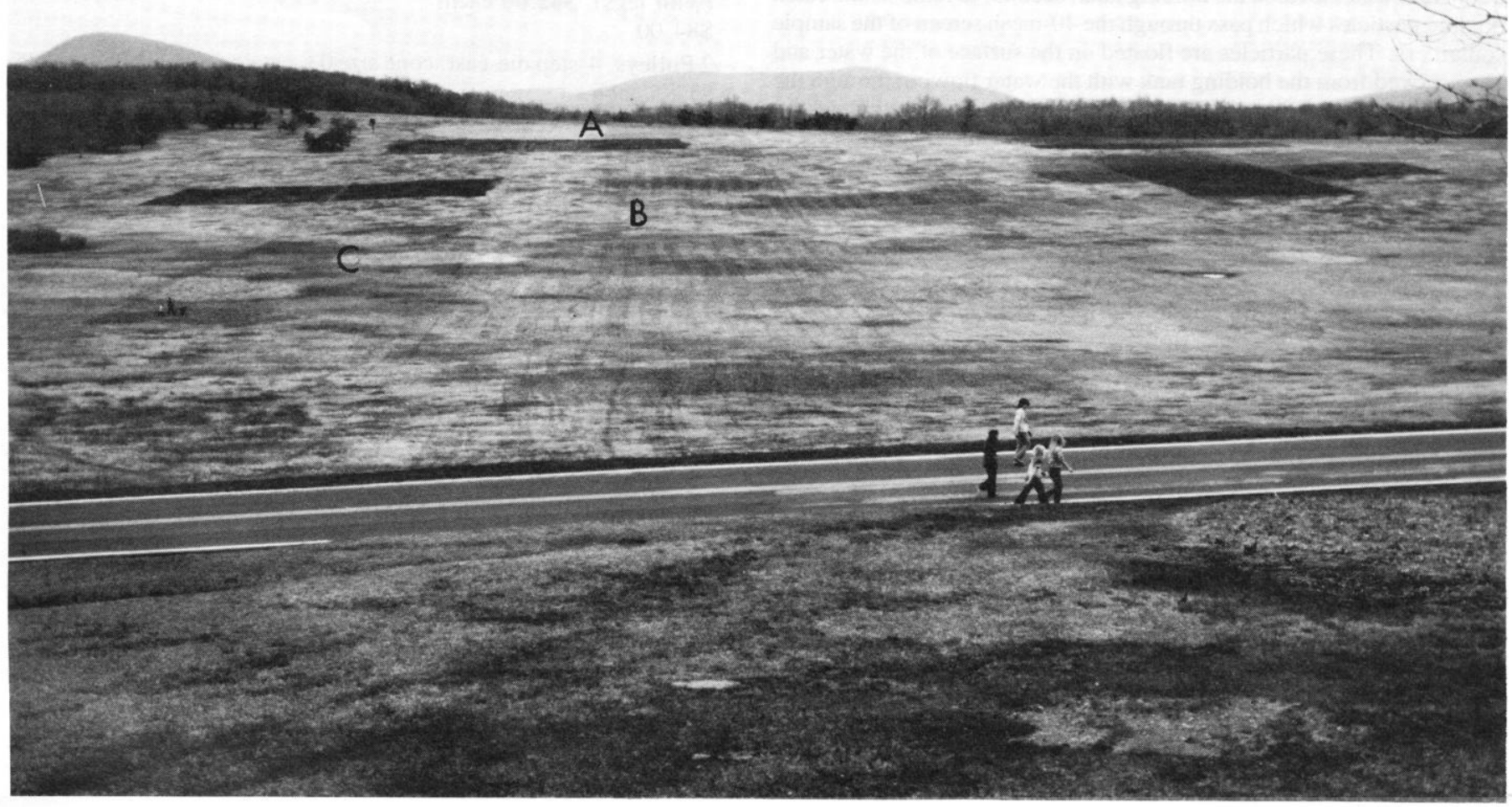

Fig. 1. Early spring aspect of Big Meadows: (A) areas burned 2 weeks prior to photograph; (B) mowed area; and (C) unmown area. (Photo by Robert Stottlemyer.) 
Table 1. Nutrient concentrations in the upper $5 \mathrm{~cm}$ of soil after various mowing and burning treatments.

\begin{tabular}{|c|c|c|c|c|c|c|c|c|c|c|}
\hline \multirow[b]{4}{*}{ Nutrient $^{1}$} & \multicolumn{2}{|c|}{ April 16} & \multicolumn{8}{|c|}{ June 15} \\
\hline & \multirow{3}{*}{$\begin{array}{c}\text { Low } \\
\text { shrub }\end{array}$} & \multirow{3}{*}{$\begin{array}{l}\text { High } \\
\text { shrub }\end{array}$} & \multicolumn{4}{|c|}{ Low shrub } & \multicolumn{4}{|c|}{ High shrub } \\
\hline & & & \multicolumn{2}{|c|}{ Unmowed } & \multicolumn{2}{|c|}{ Mowed } & \multicolumn{2}{|c|}{ Unmowed } & \multicolumn{2}{|c|}{ Mowed } \\
\hline & & & Unburned & Burned & Unburned & Burned & Unburned & Burned & Unburned & Burned \\
\hline $\mathrm{pH}$ & 4.96 & 5.05 & 4.95 & 5.05 & 4.93 & 5.01 & 4.93 & 4.90 & 4.76 & 4.92 \\
\hline $\mathrm{K}^{+}(\mathrm{ME} / 100 \mathrm{~g} \text { Soil })^{\mathrm{a}}$ & 0.60 & 0.61 & 0.23 & 0.41 & 0.33 & 0.42 & 0.33 & 0.56 & 0.31 & 0.38 \\
\hline $\mathrm{Ca}^{++}(\mathrm{ME} / 100 \mathrm{~g} \text { Soil })^{\mathrm{aa}}$ & 1.88 & 2.49 & 0.51 & 1.52 & 0.59 & 1.35 & 1.25 & 1.42 & 0.79 & 1.19 \\
\hline $\mathrm{Mg}^{++}(\mathrm{ME} / 100 \mathrm{~g} \text { Soil })^{\mathrm{aaa}}$ & 0.57 & 0.66 & 0.18 & 0.35 & 0.22 & 0.37 & 0.34 & 0.46 & 0.25 & 0.36 \\
\hline Nitrate-N ( $\mu \mathrm{g} / \mathrm{g}$ Soil $)$ aa,bb,ccc & tr. & tr. & 2.9 & 4.0 & 1.0 & 6.6 & 52.3 & 83.9 & 49.9 & 44.4 \\
\hline Ammonium-N $(\mu \mathrm{g} / \mathrm{g} \text { Soil })^{\text {aa }}$ & 42.4 & 47.7 & 84.3 & 103.2 & 106.8 & 111.2 & 91.9 & 101.4 & 91.4 & 111.8 \\
\hline Phosphorus PO $-\mathrm{P}(\mu \mathrm{g} / \mathrm{g} \text { Soil })^{\mathrm{ccc}}$ & 2.5 & 2.2 & 3.1 & 3.2 & 3.6 & 4.3 & 4.9 & 6.4 & 5.5 & 4.7 \\
\hline
\end{tabular}

'Letters indicate significance: single means $P<0.05 ; 2$ letters mean $P<0.01 ; 3$ letters mean $P<0.001 ; a$ refers to significance due to burning, $b$ due to mowing, and $c$ due to vegetational differences.

depending on the condition of the vegetation, character of the soil, and topography (Vogl, 1975). Because no data were available on nutrient changes following burning in grassy meadows of the Appalachians, the following study was undertaken.

\section{The Study}

The study areas were located in Big Meadows, elevation 1,060 m $(3,500 \mathrm{ft})$. To differentiate between possible interactions with vegetative cover, comparisons were made between areas where growth of Robinia was luxuriant (hereafter referred to as high shrub) and areas where grasses, sedges, and herbs were more common (low shrub). Two strips approximately $80 \mathrm{~m}$ wide and $160 \mathrm{~m}$ long were selected in each vegetation type. Within each strip two quadrats $(40 \times 40 \mathrm{~m})$ were selected for each of the following treatments: (1) mowed, then burned; (2) mowed, but not burned; (3) burned without mowing; and (4) control, no treatment. Mowing was done the previous November and the burn treatments applied on April 20, 1975. Thus, the treatments can be arranged in a $2 \times 2 \times 2$ factorial design as shown in Table 1 .

On April 16 prior to burning, 10 samples were collected for chemical analysis from the upper $0-5 \mathrm{~cm}$ of mineral soils in each of the high and low shrub areas. On June 15 , approximately 2 months after burning, three samples $(0-5 \mathrm{~cm})$ were again collected from each 40 $\times 40$ quadrat. Thus, each treatment within each vegetation type was represented by six soil samples. Samples were returned to Duke University and analyzed for $\mathrm{pH}$, ammonium- $\mathrm{N}$, nitrate- $\mathrm{N}$, extractable phosphate, and exchangeable potassium, calcium, and magnesium. $\mathrm{pH}$ was determined in 1:1 soil-water suspension. Ammonium and nitrate were analyzed on $2 \mathrm{~N} \mathrm{KCl}$ extracts of soil (10:1) using a Technicon Autoanalyzer. Extractable phosphate was determined on dilute $\mathrm{H}_{2} \mathrm{SO}_{4}-\mathrm{HCl}$ extracts using the molybdenum-blue method and cations were determined trom $1 \mathrm{~N}$ ammonium acetate extracts on a Beckman 485 atomic-absorption spectrophotometer. The data from the June 15 samples were compared using a computer program for factorial design analysis of variance from Dixon (1973).

\section{Results}

Concentrations of potassium, calcium, and magnesium were significantly higher in the burn treatment (Table 1). Neither mowing nor variations in vegetational cover had any significant effect on concentrations of these nutrients. Cation concentrations were consistently lower in the June samples than in those taken in April. Perhaps during the colder months rates of mineralization exceed rates of uptake, resulting in a nutrient surplus in the soil. Soil $\mathrm{pH}$ was unaffected by any treatment.

All three treatments significantly affected levels of nitrate. Burn treatments tended to have higher nitrate levels while mowed treatments were generally lower. These data are, however, somewhat variable and the magnitude of the differences rather small compared to the rather marked and highly significant differences between low and high shrub areas. Increased nitrate in the high shrub area may reflect higher rates of nitrification beneath the robust Robinia. Ammonium concentrations behaved somewhat similarly to the metallic cations, being more concentrated in burned areas. The magnitude of these differences was, however, slight considering the apparently large amounts of ammonium present in all soils.

Neither mowing, nor burning affected concentrations of phosphate although high shrub areas had higher concentrations of this element in the June 15 sample.

These data suggest that burning results in nutrient enrichment in these meadow areas. The more robust growth of the vegetation of these burned areas compared to their unburned counterparts (Cocking ct al., 1976) is probably due to these nutrient changes. The changes in vegetation and soil nutrients observed here are consistent with changes documented by $\operatorname{Vogl}(1975)$ for other grassland ecosystems. Because of the low topographic relief and slow drainage, it is doubtful that appreciable amounts of nutrients are lost due to leaching.

Burning is certainly as efficient as mowing in keeping the invading shrubs and trees under control. These data suggest that it results in more fertile soil conditions, which may promote more luxuriant growth. Because burning has no known detrimental effects on either vegetation or soil and is considerably less expensive than mowing, it would appear to be a better alternative to halt the unwanted invasion. A determination of whether it can completely halt this invasion may require several years of prescribed fire.

\section{Literature Cited}

Cocking, W. D., E. Baxter, and S. Lilly. 1976. Vegetation dynamics following controlled burning of Big Meadows, Shenandoah National Park. Bull. Ecol. Soc. Amer. 57:27.

Daubenmire, R. 1968. Ecology of fire in grasslands. Advan. Ecol. Res.. 5:209-266.

DeBell, D. S., and C. W. Ralston. 1970. Release of nitrogen by burning light forest fuels. Soil Sci. Soc. Amer. Proc. 34:936-938.

Dixon, W. J. 1973. BMD: Biomedical Computer Programs. Univ. of Caif. Press, Berkeley. 773 p.

Gersmehl, P. J. 1971. Factors involved in the persistence of southern Appalachian treeless balds: an experimental study. Proc. Ass. Amer. Geogr. 3:56-61.

Mark, A. F. 1958. The ecology of the southern Appalachian grass balds. Ecol. Monogr. 38:309-344.

Vogl. R. J. 1975. Effects of fire on grasslands. p. 139-194. In: Kozlowski, T. T., and C. E. Ahlgren, Eds. Fire and Ecosystems. Academic Press, New York, N.Y.

Wells, C. G. 1971. Effects of prescribed burned on soil chemical properties and nutrient availability, p. 86-99. In: Prescribed burning symposium proceedings. U.S. Dep. Agr., Forest Serv., Southeast Forest. Exp. Sta., Ashville, N.C.

Wilhelm, G. 1973. Fire ecology in Shenandoah National Park. Proc. Tall Timbers Fire Ecol. Conf. 12:445-488. 